\title{
Technological Self-Efficacy in Teaching Physical Education and Health among Junior High School Teachers
}

\author{
Rayvin D. Pestano ${ }^{1}$ \\ ${ }^{1}$ Faculty, Institute of Sports, Physical Education and Recreation, College of Education, Central Luzon State \\ University, Science City of Munoz, 3119, Nueva Ecija, Philippines
}

\begin{abstract}
Purpose: This study assessed the Technological self-efficacy of 26 junior high school teachers of Physical Education and Health in Juan R. Liwag Memorial High School.

Methodology: using descriptive correlational research design, their socio-demographic characteristics, level of their technological self-efficacy and performance rating were the variables of the study. Quantitative data were gathered using a questionnaire as the main instrument. In terms of sampling method, total enumeration sampling was utilized.

Findings: Majority of the respondents were female, young with educational attainment varying from bachelor's degree to master's degree and have been in the service from 1-10 years. Overall technological self-efficacy was low level in the five components namely; technological knowledge, technological content knowledge, technological pedagogical knowledge and technological pedagogical content knowledge and high in pedagogical knowledge and pedagogical content knowledge. Pedagogical knowledge and pedagogical content knowledge had a positive relationship with performance rating. On the other hand, technological knowledge, technological content knowledge, technological pedagogical knowledge and technological pedagogical content knowledge were found to be negatively correlated with performance rating. Technological content knowledge was found to be predictive of physical education and health teacher's performance rating.

Contribution and Recommendation: Thus, it is highly recommended to sustain and enhance the technological content knowledge of physical education and health teachers since it is detrimental to their performance.
\end{abstract}

Keywords Physical Education and Health Teachers, Technological Self-Efficacy

\section{Introduction}

The Department of Education recognizes the vital role of technology in teaching and learning process. In its thrust to raise the information and communication technology (ICT) literacy to learners, teachers, and school heads, the DepEd promote the integration of ICT in the educational system [1]. To further the development of 21st century skills and to produce globally competent student, teachers must be equipped in utilizing technology in educational process. Thus, integration of technology in education has become a necessity [2]; [3].

Technology integration in education can be defined as the use of technology as a tool for enhancing student learning, better understanding of course content, and the development of high-level thinking skills [4]. According to Wachira and Keengwe [5] technology integration in education; can be defined as the integration of the learning and teaching process with appropriate technology for the objectives, including the evaluation of lessons and learning outcomes. Thus, it makes technology an integral part of educational process.

Integrating technology into teaching is among the greatest challenges facing today's teachers [6]. In teaching physical education and health to $21 \mathrm{st}$ century learners required teacher's to have some degree of competency in using technology in the class. Tech-inclusive pedagogies and activity approaches are needed to teach meaningfully in the 
class [7]. In this view, today's Physical Education and Health teachers are expected to integrate technology effectively in their pedagogy (method) which is imperative in the teaching and learning process. In its broadest sense, pedagogical competency is the ability to do or perform something successfully or efficiently. Specifically, it is concerned into teaching capacity, from lesson plans to approaches, to teaching performance including classroom management. Moreover, the term can also be applied to individual or group of people who are engaged in distinct skills and activities that each one has engaged in [8]. Technology integration qualification is addressed by technological self-efficacy and Technological Pedagogical Content Knowledge. The former is a belief in one's ability to successfully perform a technologically sophisticated task. The latter is a framework that synthesized output or product of the three areas of knowledge; technology, pedagogy (teaching and student learning), and content [9]. The TPACK framework can help design, develop, and evaluate the quality of technology integration [10]. Also, teacher development when integrating technology can be identified through TPACK development model before meeting the Physical Education and Health teacher TPACK standards.

Technological self-efficacy and Technological Pedagogical Content Knowledge (TPACK) framework is seen as one of the constructs of technology integration process. The TPACK model demonstrates which components constitute teacher knowledge for effective technology integration. TPACK is designed as a seven-component model that reveals the links between technology knowledge (TK), pedagogical knowledge (PK) and content knowledge (CK) [9]. TPACK is a pedagogical way of knowing how to teach contents using the most appropriate technology for the teaching.

The effect of technology is increasing gradually in the education process. Educators with high self-efficacy perceptions strive greatly to accomplish things. Self-efficacy is a central tenet of Albert Bandura's [11] social cognitive theory. Self-efficacy is the belief, or confidence, that one can successfully execute a behavior required to produce an outcome such that the higher the level of self-efficacy, the more an individual believes he or she can execute the behavior necessary to obtain a particular outcome [11].

Here in the Philippines, junior high school teachers are expected to have high level of teaching competencies in the areas of Physical Education, and Health. Equally important, each teacher should manifest certain level technological self-efficacy both in applied and knowledge-based facts. This is to ensure the quality of instruction in the transmission of knowledge to students. Technological self-efficacy has repeatedly been reported as a major component in understanding the frequency and success with which individuals use technology [12]. It can be postulated that teachers' beliefs regarding their capacity to work effectively with technology in general are directly related to their integration of technology in teaching. Physical Education and Health teachers' technological self-efficacy is necessary and important if they want to connect with digital natives and specially to develop 21 st century skills of these learners. Given this unique implication of technological self-efficacy together with technological pedagogical content knowledge in the teaching and learning process, the purpose of this inquiry is to assess the technological self-efficacy of physical education and health teachers and its significance to their performance rating.

\subsection{Problem Statement}

The K12 curriculum is a system of education under the Department of Education, "K" stands for kindergarten and " 12 " refers to the succeeding 12 years of basic education. It generally aims to enrich learners basic skills, produce competent individuals prepared for work and higher studies. The K12 curriculum emphasized the integration of technology in the teaching learning process to cater 21 st century skills of learners [13]. As ICT integration has led to significant changes in teaching and learning process in classroom, teachers must be knowledgeable in utilizing technology to deliver quality teaching in their subject areas. Some research literature shows that teachers are inefficient in regard of their subject-specific use of ICTs [14] and they also do not have the necessary knowledge and experience to incorporate technologies into classroom teaching and learning process [15]. Technological pedagogical content knowledge of teachers is 
deemed vital in providing quality education and meaningful learning experiences among students. Instructions and day to day delivery are shaped and affected by the teacher's accumulated knowledge on the use of technology and content pedagogy in teaching any kind of subjects. Inadequate knowledge on different kind of pedagogical approaches and teaching strategies on the use of technology in educational processes hinder physical education and health teachers in enriching and developing the 21 st century technology-rich learners, thus experiencing low self-efficacy in integrating technology on this specific subject. In the same way, teachers even lose their enthusiasm in using technology in teaching and learning process and rely only on a pure lecture method in delivering the lesson.

\subsection{Research Objectives}

To describe the socio-demographic profile of the respondents in terms of age, sex, bachelor's degree, highest educational attainment and years in service.

To determine the technological self-efficacy of the respondents in terms of : technological knowledge (TK), content knowledge (CK), pedagogical knowledge (PK), Technological content knowledge (TCK), pedagogical content knowledge (PCK), technological pedagogical knowledge (TPK), and technological pedagogical content knowledge (TPACK).

To describe the performance rating of the respondents.

To determine whether technological self-efficacy of the respondents has a significant relationship with their performance rating.

\subsection{Research Hypothesis}

a) There is statistically significant relationship between technological pedagogical content knowledge and performance rating of physical education and health teachers.

\subsection{Study Significance}

The results of this study will give substantial evidences on the nature of pedagogical competencies and technological self-efficacy of the respondents. Thus, findings will provide administrators and school heads ample knowledge in enhancing the technological pedagogical content knowledge and to further improve the performance of physical education and health teachers.

\subsection{Research Terminologies}

Technological Self-Efficacy- one's perceived ability to use and integrate technology into content and pedagogy in teaching and learning process.

Technological Knowledge (TK)-pertains to knowledge about standard technologies, such as books, chalk and blackboard, and more advanced technologies, such as the Internet and digital video. This involves the skills required to operate particular technologies.

Content Knowledge (CK)-refers to knowledge about the actual subject matter that is to be learned or taught.

Pedagogical Knowledge (PK)- pertains to deep knowledge about the processes and practices or methods of teaching and learning and how it encompasses, among other things, overall educational purposes, values, and aims.

Pedagogical Content Knowledge (PCK)-refers to knowledge of pedagogy that is applicable to the teaching of specific content. This knowledge includes knowing what teaching approaches fit the content, and likewise, knowing how elements of the content can be arranged for better teaching.

Technological Content Knowledge (TCK)- refers to knowledge about the manner in which technology and content are reciprocally related. Although technology constrains the kinds of representations possible, newer technologies often afford newer and more varied representations and greater flexibility in navigating across these representations.

Technological Pedagogical Knowledge (TPK)refers to knowledge of the existence, components, and capabilities of various technologies as they are used in teaching and learning settings, and conversely, knowing how teaching might change as the result of using particular technologies.

Technological Pedagogical Content Knowledge 
(TPACK)- pertains to the basis of good teaching with technology and requires an understanding of the representation of concepts using technologies; pedagogical techniques that use technologies in constructive ways to teach content; knowledge of what makes concepts difficult or easy to learn and how technology can help redress some of the problems that students face.

Performance Rating- a term used to measure the overall level of works rendered by a teacher in a certain school year or academic year.

\section{Body}

This study utilized a Quantitative Descriptive and Correlation research design to identify, analyze, and describe the technological self-efficacy and performance of physical education and health teachers. A total of 26 physical education and health teachers participated in this research using total population sampling to provide complete and accurate information. According to Bernard [16] total population sampling involves examining the whole population that has a particular set of characteristics. The researcher requested the school principal for the conduct of the study. The instrument used was adapted from Schmidt's [17] "Pre Service Teachers Teaching Knowledge" and revised according to the needs of the study. The questionnaire used in this study focused on technological knowledge, content knowledge, pedagogical knowledge, pedagogical content knowledge, technological pedagogical knowledge, technological content knowledge and technological pedagogical content knowledge Furthermore, to determine the physical education and health teacher's performance, the data from school were used through the summarized individual performance commitment and review forms which were derived from content knowledge and pedagogy, diversity of learners \& assessment and reporting, curriculum and planning, accomplishment and professional development areas. More so, the test of reliability on internal consistency in SPSS shows a Cronbach's alpha coefficient $(\alpha)$ of .799.

The data were analyzed based on the research objectives using different statistical methods in Statistical Package for Social Sciences (SPSS). Descriptive statistics such as frequency, percentage and mean were used to describe the socio-demographic profile and technological self-efficacy of the respondents. Furthermore, to determine the relationship between technological self-efficacy and performance rating of the respondents, Pearson Correlation was used.

\section{Result and Discussion}

Based on the results of the study on the TPACK of physical education and health teachers, the following results are gathered:

Table 1. Socio-Demographic Profile of the Respondents

\begin{tabular}{|l|l|l|}
\hline $\begin{array}{l}\text { Socio-Demographic } \\
\text { Profile }\end{array}$ & $\begin{array}{l}\text { Frequency } \\
\text { (f) }\end{array}$ & $\begin{array}{l}\text { Percentage } \\
\text { (\%) }\end{array}$ \\
\hline Age & 10 & \\
\hline $20-29$ & 4 & $38 \%$ \\
\hline $30-39$ & 5 & $15 \%$ \\
\hline $40-49$ & 5 & $19 \%$ \\
\hline $50-59$ & 2 & $19 \%$ \\
\hline $60-$ Above & & $8 \%$ \\
\hline Sex & 12 & \\
\hline Male & 14 & $56 \%$ \\
\hline Female & & \\
\hline Bachelor's Degree & 12 & $46 \%$ \\
\hline BSED P.E \& Health & 12 & $54 \%$ \\
\hline BSED w/ Other Major & 14 & \\
\hline $\begin{array}{l}\text { Highest Educational } \\
\text { Attainment }\end{array}$ & & \\
\hline Bachelor's Degree & 9 & $35 \%$ \\
\hline With Masters Units & 11 & $42 \%$ \\
\hline Master's Degree & 6 & $23 \%$ \\
\hline Years in Service & & \\
\hline $1-10$ & 12 & 46 \\
\hline $11-20$ & 10 & 38 \\
\hline $21-30$ & 2 & 8 \\
\hline 31-Above & 2 & 8 \\
\hline
\end{tabular}

Table 1 shows the age of the respondents. It is presented in the table that 10 or $38 \%$ of the respondents are young, while 14 or $54 \%$ of the respondents are under 20-29 years old while four or $15 \%$ of them are 30-39 years old. Moreover, five or $19 \%$ belong to the age range of $40-49$ and $50-59$ years old, and lastly, two or $8 \%$ of them are 60 and above. The findings implies that majority of the respondents were 20-29 years old. 
Rayvin D. Pestano et./al Technological Self-Efficacy in Teaching Physical Education and Health among Junior High School Teachers

In terms of sex, it can be seen on the table that 12 or $46 \%$ of the respondents were male and while 14 or $54 \%$ were female. This implies that female teachers dominated the teaching force of physical education and health subject in Juan R. Liwag Memorial High School.

On the other hand, as to bachelor's degree, it can be noticed that 12 or $46 \%$ were BSED P.E and Health major, while 14 or $54 \%$ were BSED with Other Major. This indicates that majority of the respondents were non-majors of P.E and Health major and was hired because of necessity regardless of specialization of the teacher.

With regards to highest educational attainment of the respondents, Table 1 shows that nine or $35 \%$ of respondents were bachelors' degree holder while 11 or $42 \%$ taken masters units and six or $23 \%$ graduated in their masters' degree program. However, the data shows that no one among them finished doctoral degree or taken doctoral units.

In reference with years in service of the respondents.it can be observed on the table that 12 or $46 \%$ of the respondents have been in the service for $1-10$ years while 10 or $38 \%$ have been in the service for 11-20 years. Moreover, two or $8 \%$ of the respondents have been in the service for 21-30 and 31 and above. Harris and Sass [18] stated that teachers with more than five years of experience are more effective than teachers with no experience. Hence, teachers with more years of experience tend to increase effectiveness in teaching.

Table 2. Technological Self-Efficacy of the Respondents

\begin{tabular}{|l|l|l|}
\hline $\begin{array}{l}\text { Technological } \\
\text { Pedagogical } \\
\text { Content } \\
\text { Knowledge }\end{array}$ & Mean & $\begin{array}{l}\text { Verbal } \\
\text { Description }\end{array}$ \\
\hline $\begin{array}{l}\text { Technological } \\
\text { Knowledge }\end{array}$ & 1.54 & Low \\
\hline $\begin{array}{l}\text { Content } \\
\text { Knowledge }\end{array}$ & 1.70 & Low \\
\hline $\begin{array}{l}\text { Pedagogical } \\
\text { Knowledge }\end{array}$ & 3.52 & Very High \\
\hline $\begin{array}{l}\text { Technological } \\
\text { Content } \\
\text { Knowledge }\end{array}$ & 1.61 & Low \\
\hline
\end{tabular}

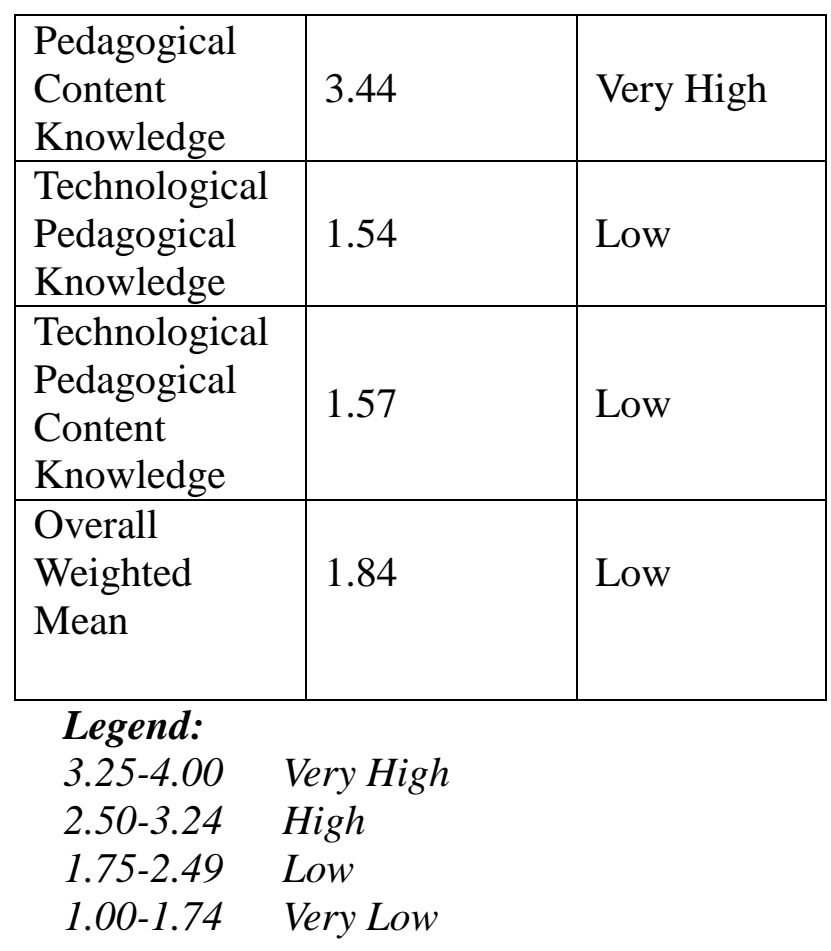

Technological self-efficacy of the respondents was shown through weighted mean and rating description. It can be noticed that under the Technological self-efficacy of the respondents, two TPACK components such as pedagogical knowledge and pedagogical content knowledge received very high level of proficiencies. Conversely, technological knowledge, technological content knowledge, technological pedagogical knowledge and technological pedagogical content knowledge obtained low level of proficiencies. The overall Technological self-efficacy of the respondents got a grand weighted mean of 1.84 with the description of low level of Technological self-efficacy.

Table 3. Performance Rating of the Respondents

\begin{tabular}{|l|l|l|}
\hline $\begin{array}{l}\text { Performance } \\
\text { Rating }\end{array}$ & $\begin{array}{l}\text { Frequency } \\
\text { (f) }\end{array}$ & $\begin{array}{l}\text { Percentage } \\
(\%)\end{array}$ \\
\hline Outstanding & 10 & $38 \%$ \\
\hline $\begin{array}{l}\text { Very } \\
\text { Satisfactory }\end{array}$ & 16 & $62 \%$ \\
\hline Satisfactory & 0 & $0 \%$ \\
\hline Unsatisfactory & 0 & $0 \%$ \\
\hline Poor & 0 & $0 \%$ \\
\hline Total & 26 & $100 \%$ \\
\hline
\end{tabular}

$\begin{array}{lc}\text { Legend: } & \\ 4.50-5.0 & \text { Outstanding } \\ 3.50-4.49 & \text { Very Satisfactory } \\ 2.50-3.49 & \text { Satisfactory }\end{array}$




\subsection{0-2.49 Unsatisfactory \\ 1.49 below Poor}

Table 3 shows the performance rating of the respondents. It can be observed in the data that 10 or $38 \%$ of the respondents have an outstanding performance while 16 or $62 \%$ have a very satisfactory performance.

Table 4. Relationship between Technological Self-Efficacy and Performance of the Respondents

\begin{tabular}{|c|c|}
\hline $\begin{array}{l}\text { Technological } \\
\text { Self-Efficacy }\end{array}$ & Performance \\
\hline Technological Knowledge & $-.947 * *$ \\
\hline Content Knowledge & $-.393 *$ \\
\hline Pedagogical Knowledge & $.883 * *$ \\
\hline $\begin{array}{l}\text { Technological Content } \\
\text { Knowledge }\end{array}$ & $.870 *$ \\
\hline $\begin{array}{l}\text { Technological } \\
\text { Pedagogical Knowledge }\end{array}$ & $-.951 * *$ \\
\hline $\begin{array}{l}\text { Technological } \\
\text { Pedagogical Content } \\
\text { Knowledge }\end{array}$ & $-.921 * *$ \\
\hline Total & $100 \%$ \\
\hline
\end{tabular}

*. Correlation is significant at the 0.05 level (2-tailed).

The technological self-efficacy in terms of technological knowledge, technological content knowledge, technological pedagogical knowledge and technological pedagogical content knowledge has been found to have high significant relationship with performance rating. Because of its negative relationship, the result might imply that as the TK, TCK, TPK and TPACK increases the performance rating decreases. The findings denotes that, high level of technological self-efficacy components, specifically technological knowledge, technological content knowledge, technological pedagogical knowledge and the TPACK is not necessary to have high performance rating but needed to improve the facilitation of teaching and learning process.

Pedagogical knowledge and pedagogical content knowledge was found to have high positive significant relationship with performance rating.
The findings disclosed that as the performance rating increases, the more likely to develop not just knowledge on pedagogy but as well as pedagogical content. The results suggest that in order to have high performance rating, teacher must invest in developing and enriching their pedagogical knowledge and pedagogical content knowledge. That is acquiring knowledge about the method of teaching and learning and also the strategies and approaches that will significantly compliment the teaching of specific content or subject matter.

\section{Conclusion}

Based on the results, it is indicated that respondents revealed to have low level of Technological self-efficacy. Specifically, they reported low level in the five components of TPACK assessed in this study, these are technological knowledge, technological content knowledge, technological pedagogical knowledge and technological pedagogical content knowledge.In terms of performance, majority of them have a very satisfactory rating. Furthermore, teachers who have high level of pedagogical knowledge and pedagogical content knowledge revealed to have higher performance rating compare to those teachers with high level of technological knowledge, technological content knowledge, technological pedagogical knowledge and technological pedagogical content knowledge.

\section{Recommendation}

Since physical education and health teachers who have high level of technological knowledge, technological content knowledge, technological pedagogical content knowledge have lower performance rating compare to physical education and health teachers with high level of pedagogical knowledge and pedagogical content knowledge. Therefore, teachers should be trained in improving their pedagogy. Institution must revisit the existing physical education and health curriculum and give more importance in developing pedagogy. Furthermore, the school should conduct in-service training that will focus on the development of pedagogy in teaching.

\section{Limitation}

The only limitation of this study is of considerable concern is that the result is based only on the perception technological self-efficacy 
ofteacher-respondents themselves.

\section{Acknowledgement}

No external financial support was received for this study. The author would like to thank all the respondents who participated in this study.

\section{References}

1. DepEd Order No. 78 s., "DepEd Order No. 78, s. 2010 Guidelines on the Implementation of DepED Computerization Program (DCP).” 2010.

2. D. Z. Dumpit and C. J. Fernandez, "Analysis of the use of social media in Higher Education Institutions (HEIs) using the Technology Acceptance Model," Int. J. Educ. Technol. High. Educ., vol. 14, no. 1, 2017, doi: 10.1186/s41239-017-0045-2.

3. Y. kuang C. Liao, "Effects of computer-assisted instruction on students' achievement in Taiwan: A meta-analysis," Comput. Educ., vol. 48, no. 2, pp. 216-233, 2007, doi: 10.1016/j.compedu.2004.12.005.

4. J. Reynolds, "Secondary preservice teachers' perceptions of preparation to teach in urban schools," ProQuest Diss. Theses, p. 174, 2016, [Online]. Available: https://search.proquest.com/dissertations-th eses/secondary-preservice-teachers-percepti ons $/$ docview $/ 1811953089 / \mathrm{se}-2$ ?accountid= 41849.

5. J. Keengwe, G. Onchwari, and P. Wachira, "Computer technology integration and student learning: Barriers and promise," $J$. Sci. Educ. Technol., vol. 17, no. 6, pp. 560565, 2008, doi: 10.1007/s10956-008-9123-5.

6. K. Cennamo, J. Ross, and P. Ertmer, "Technology Integration for Meaningful Classroom Use: A Standards-Based Approach," p. 416, 2013.

7. A. Kent and R. Giles, "Preservice Teachers' Technology Self-Efficacy.," SRATE J., vol. 26, no. 1, pp. 9-20, 2017.

8. M. Rita and B. Brenda, "Facilitating Learning: A Metacognitive Process ( 3rd Edition ) Related products."

9. M. J. Koehler and P. Mishra, "Technological Pedagogical Content Knowledge: A Framework for Teacher Knowledge PUNYA MISHRA," Teach. Coll. Rec., vol. 108, no. 6, pp. 1017-1054,
2006, [Online]. Available: http://one2oneheights.pbworks.com/f/MIS HRA_PUNYA.pdf.

10. J. S. Bowers and B. Stephens, "Using technology to explore mathematical relationships: A framework for orienting mathematics courses for prospective teachers," J. Math. Teach. Educ., vol. 14, no. 4, pp. 285-304, 2011, doi: 10.1007/s10857-011-9168-x.

11. A. Bandura, "Self-efficacy: Toward a unifying theory of behavioral change," $A d v$. Behav. Res. Ther., vol. 1, no. 4, pp. 139161, 1978, doi: 10.1016/0146-6402(78)90002-4.

12. S. Sure, "DEVELOPMENT OF A TOOL TO MEASURE COMPUTER SELF-EFFICACY OF STUDENT TEACHERS Sharad Sure," 2009.

13. DepEd Order No. 21, “DO_s2019_021." p. 19, 2019.

14. B. Kramarski and T. Michalsky, "Preparing preservice teachers for self-regulated learning in the context of technological pedagogical content knowledge," Learn. Instr., vol. 20, no. 5, pp. 434-447, 2010, doi: 10.1016/j.learninstruc.2009.05.003.

15. J. a Buckenmeyer and D. J. Freitas, "No Computer Left Behind: Getting Teachers on Board with Technology No Computer Left Behind: Getting Teachers on Board with Technology," no. July, pp. 1-18, 2005.

16. H. R. Bernard, Research in Anthropology, Fourth Edi. 2006.

17. D. a. Schmidt, E. Baran, A. D. Thompson, M. J. Koehler, P. Mishra, and T. Shin, "Survey of Preservice Teachers' Knowledge of Teaching and Technology," Iowa State Univ. ..., pp. 1-8, 2009. 